\title{
Contents of Carboxylic Acids and Two Phenolics and Antioxidant Activity of Dried Portuguese Wild Edible Mushrooms
}

\author{
Bárbara Ribeiro, ${ }^{\dagger}$ Joana Rangel,${ }^{\dagger}$ Patrícia Valentão,${ }^{\dagger}$ Paula Baptista,, \\ Rosa M. Seabra, ${ }^{\dagger}$ and Paula B. Andrade ${ }^{*}, \dagger$ \\ REQUIMTE/ Serviço de Farmacognosia, Faculdade de Farmácia, Universidade do Porto, R. Aníbal \\ Cunha 164, 4050-047 Porto, Portugal, and CIMO/ESAB, Quinta de Sta Apolónia, Apartado 1172, \\ 5301-855 Bragança, Portugal
}

\begin{abstract}
The organic acids and phenolics compositions of nine wild edible mushrooms species (Suillus bellini, Tricholomopsis rutilans, Hygrophorus agathosmus, Amanita rubescens, Russula cyanoxantha, Boletus edulis, Tricholoma equestre, Suillus luteus, and Suillus granulatus) were determined by HPLC-UV and HPLC-DAD, respectively. The antioxidant potential of these species was also assessed by using the $\mathrm{DPPH} \cdot$ scavenging assay. The results showed that all of the species presented a profile composed of at least five organic acids: oxalic, citric, malic, quinic, and fumaric acids. In a general way, the pair of malic plus quinic acids were the major compounds. Only very small amounts of two phenolic compounds were found in some of the analyzed species: $p$-hydroxybenzoic acid (in $A$. rubescens, R. cyanoxantha, and T. equestre) and quercetin (in S. luteus and S. granulatus). All of the species exhibited a concentration-dependent scavenging ability against $\mathrm{DPPH} \cdot$. T. rutilans revealed the highest antioxidant capacity.
\end{abstract}

KEYWORDS: Wild edible mushrooms; organic acids; phenolic compounds; antioxidant potential

\section{INTRODUCTION}

The search for new natural products with antioxidant properties is a very active domain of research. Antioxidant supplements or antioxidant-containing foods may be used to help the human body to reduce oxidative damage. Free radicals are produced in normal and/or pathological cell metabolism. In fact, oxidation is essential to many living organisms for the production of energy to biological processes. However, the uncontrolled production of oxygen-derived free radicals is involved in the onset of many diseases, such as cancer, rheumatoid arthritis, cirrhosis, and arteriosclerosis, as well as in degenerative processes associated with aging (1).

Among phytochemicals, phenolic compounds and organic acids may contribute to the protection against various diseases, due to their antioxidant potential (2). In addition, these compounds are well-known for their determinant role in maintaining fruit and vegetable quality and organoleptic characteristics and have also been used in their quality control (3$6)$.

Mushrooms are very appreciated, not only for their texture and flavor, but also for their nutritional properties. They have been described as therapeutic foods, useful in preventing

* Author to whom correspondence should be addressed (telephone + 351 222078935; fax + 351 222003977; e-mail pandrade@ff.up.pt).

REQUIMTE.

$\div$ CIMO/ESAB diseases such as hypertension, hypercholesterolemia, and cancer. These functional characteristics are mainly due to their chemical composition (7). Previous works with this food matrix revealed the presence of organic acids $(8,9)$ and phenolic compounds $(9,10)$ in several species. In addition, mushrooms' antioxidant potential has also been reported $(11-15)$.

The Trás-os-Montes region (northeastern Portugal) is known for the variety of its soils and diversity of climatic conditions. This variability assumes an important role in mushroom production and, thus, Trás-os-Montes is recognized as one of the richest regions in wild edible species. Among them, Suillus bellini is one of the most collected and eaten wild mushroom species.

Nine wild edible mushroom species collected in this region were studied in the present work: Suillus bellini, Suillus luteus, Suillus granulatus, Tricholomopsis rutilans, Hygrophorus agathosmus, Amanita rubescens, Russula cyanoxantha, Boletus edulis, and Tricholoma equestre. As far as we know, with the exception of B. edulis, there's no knowledge about the organic acids and phenolics compositions or about the antioxidant activity of these species.

Despite this, several works have already involved them. In the case of $T$. rutilans, its influence was studied on the binding of lipopolysaccharides to $\mathrm{CD} 14^{+}$cells and on the release of inflammatory mediators (16), the isolation of sterol esters (17), and the translocation of soil-derived phosphorus in its mycelia cord systems in relation to inoculum resource size (18). 
Table 1. Characterization of Mushroom Samples

\begin{tabular}{|c|c|c|c|c|c|}
\hline sample & species & origin & orchard & field & date of collection \\
\hline 1 & Suillus bellini & Bragança & Pinus pinaster & 1 & November 2004 \\
\hline 2 & S. bellini & Bragança & Pinus pinaster & 2 & November 2004 \\
\hline 3 & Tricholomopsis rutilans & Bragança & Pinus pinaster & 1 & December 2004 \\
\hline 4 & T. rutilans & Bragança & Pinus pinaster & 2 & December 2004 \\
\hline 5 & Hygrophorus agathosmus & Bragança & Pinus pinaster & 1 & November 2004 \\
\hline 6 & H. agathosmus & Vinhais & Pinus pinaster + Castanea sativa & a & December 2005 \\
\hline 7 & Amanita rubescens & Bragança & Castanea sativa & 1 & June 2005 \\
\hline 8 & Russula cyanoxantha & Bragança & Castanea sativa & 1 & June 2005 \\
\hline 9 & R. cyanoxantha & Bragança & Castanea sativa & 2 & June 2005 \\
\hline 10 & R. cyanoxantha & Bragança & Castanea sativa & 3 & June 2005 \\
\hline 11 & Boletus edulis & Bragança & Castanea sativa & 1 & June 2005 \\
\hline 12 & B. edulis & Bragança & Castanea sativa & 2 & June 2005 \\
\hline 13 & B. edulis & Bragança & Castanea sativa & 3 & June 2005 \\
\hline 14 & Tricholoma equestre & Carrazeda de Ansiães & Pinus pinaster & 1 & November 2005 \\
\hline 15 & T. equestre & Carrazeda de Ansiães & Pinus pinaster & 2 & November 2005 \\
\hline 16 & Suillus luteus & Vinhais & Pinus pinaster + Castanea sativa & 1 & November 2005 \\
\hline 17 & S. luteus & Vinhais & Pinus pinaster + Castanea sativa & 2 & November 2005 \\
\hline 18 & S. luteus & Vinhais & Pinus pinaster + Castanea sativa & 3 & November 2005 \\
\hline 19 & S. luteus & Bragança & Pinus pinaster + Castanea sativa & 1 & November 2005 \\
\hline $20 \mathrm{~A}$ & Suillus granulatus & Carrazeda de Ansiães & Pinus pinaster & $a$ & November 2005 \\
\hline $20 \mathrm{~B}$ & S. granulatus & Carrazeda de Ansiães & Pinus pinaster & $a$ & November 2005 \\
\hline $20 \mathrm{C}$ & S. granulatus & Carrazeda de Ansiães & Pinus pinaster & $a$ & November 2005 \\
\hline 21 & S. granulatus & Macedo de Cavaleiros & Pinus pinaster & 1 & November 2005 \\
\hline 22 & S. granulatus & Macedo de Cavaleiros & Pinus pinaster & 2 & November 2005 \\
\hline 23 & S. granulatus & Macedo de Cavaleiros & Pinus pinaster & 3 & November 2005 \\
\hline $24 \mathrm{~A}$ & S. granulatus & Vinhais & Pinus pinaster + Castanea sativa & $a$ & November 2005 \\
\hline 24B & S. granulatus & Vinhais & Pinus pinaster + Castanea sativa & $a$ & November 2005 \\
\hline $24 C$ & S. granulatus & Vinhais & Pinus pinaster + Castanea sativa & $a$ & November 2005 \\
\hline 25 & S. granulatus & Vila Flor & Pinus pinaster & $a$ & November 2005 \\
\hline 26 & S. granulatus & Bragança & Pinus pinaster & $a$ & November 2005 \\
\hline 27 & S. granulatus & Bragança & Pinus pinaster & 1 & November 2005 \\
\hline 28 & S. granulatus & Bragança & Pinus pinaster & 2 & November 2005 \\
\hline
\end{tabular}

a Same alleatory field.

For A. rubescens, previous works concerned the phallotoxins (19), the accumulation of several heavy metals and lanthanides (20), the taxonomy (21), and the toxic effects caused by a hemolytic protein from this species (22).

Earlier studies on $R$. cyanoxantha reported the heavy metal bioaccumulation (23), the concentration of metals (24), and the impact of artificial acid rain and liming on its fruit body production (25).

Relative to $B$. edulis, the impact of geological origin on its trace element composition (26), the concentrations of lead, cadmium, mercury, and copper (27), the dietary fiber, chitin, and total phenolic contents (28), the flavor constituents (29), and the increase of its productivity (30) were studied.

For S. luteus is already described its allergic potential (31), free amino acid (32) and selenium contents (33), its radiocesium activity (34), and a Polymerase Chain Reaction for its detection in food samples (35).

With regard to $S$. granulatus, the effects of litter addition (36), the determination of mercury (37), radiocesium, and potassium (38), the amino acid composition (39), the genetic diversity, and interrelationships with other common European Suillus species (40) have been previously reported.

T. equestre is also an edible species that deserves particular attention because, despite being consumed in many countries, it is very toxic. Cases of delayed rhabdomyolysis are described in France after meals that included large quantities of $T$. equestre $(41,42)$, due to the presence of a myotoxin.

To our knowledge, nothing has been reported about S. bellini and $H$. agathosmus.

The aim of the work presented herein was to study the chemical composition of wild mushrooms consumed in Portugal, relative to phenolic compounds and organic acids, and to assess their antioxidant potential. To define the phenolics and organic acids profiles, we carried out HPLC-diode array (HPLC-DAD) and HPLC-UV analyses, respectively. The extracts were also evaluated for their antioxidant potential against $\mathrm{DPPH}^{\bullet}$.

\section{MATERIALS AND METHODS}

Standards and Reagents. Oxalic, citric, malic, ketoglutaric, quinic, succinic, shikimic, fumaric, and $p$-hydroxybenzoic acids, quercetin, and $\mathrm{DPPH}^{\bullet}$ were purchased from Sigma (St. Louis, MO). cis-Aconitic acid was from Extrasynthése (Genay, France). Methanol and formic and ascorbic acids were obtained from Merck (Darmstadt, Germany), and sulfuric acid was from Pronalab (Lisboa, Portugal). The water was treated in a Milli-Q water purification system (Millipore, Bedford, MA).

Samples. Samples of mushroom fruiting bodies were collected from different places in Trás-os-Montes, and their characterization is given in Table 1. The difference in the number of analyzed samples for each species is related to the fact that they are not cultivated; that is, only wild-growing available samples were studied. Each sample was composed of one to four different fruiting bodies collected under the same conditions.

After collection, the mushrooms were immediately transferred to the laboratory. Taxonomic identification followed that of several authors (43-48). Representative voucher specimens were deposited at the herbarium of Escola Superior Agrária, Instituto Politécnico de Bragança. Samples were dehydrated in a ventilated stove at $30^{\circ} \mathrm{C}$, for 4 days, and kept in the dark in hermetically sealed plastic bags.

Phenolic Compounds Screening Tests. To check for the presence of phenolic compounds an extract was prepared by thoroughly mixing ca. $1 \mathrm{~g}$ of powdered sample $(910 \mu \mathrm{m})$ with $5 \times 50 \mathrm{~mL}$ of methanol, at $40{ }^{\circ} \mathrm{C}$. $\mathrm{NaOH} 20 \%$ and $\mathrm{FeCl}_{3} 4.5 \%$ were then added to two aliquots of the resulting extract.

Extraction of Phenolics and Organic Acids. For the chemical characterization and antioxidant activity assay, an aqueous extract was prepared: ca. $10 \mathrm{~g}$ of powdered mushroom $(910 \mu \mathrm{m})$ was boiled in 
$500 \mathrm{~mL}$ of water during $30 \mathrm{~min}$ and then filtered over a Büchner funnel. The resulting extract was then lyophilized in a Labconco 4.5 Freezone apparatus (Kansas City, MO), and a yield of ca. $0.713 \mathrm{~g}$, on average, was obtained. The lyophilized extracts were kept in an exsicator, in the dark, at room temperature.

For organic acids analysis, the lyophilized extracts were redissolved in $0.01 \mathrm{~N}$ sulfuric acid. For phenolic compounds determination, water was used to redissolve the lyophilized extracts.

HPLC Analysis of Organic Acids. The separation of the organic acids was carried out as previously reported (49). The system consisted of an analytical HPLC unit (Gilson) in conjunction with a column heating device set at $30^{\circ} \mathrm{C}$, with an ion exclusion column, Nucleogel Ion $300 \mathrm{OA}(300 \times 7.7 \mathrm{~mm})$. Elution was carried out isocratically with $0.01 \mathrm{~N}$ sulfuric acid as mobile phase, at a flow rate of $0.2 \mathrm{~mL}$ $\min ^{-1}$. The injection volume was $20 \mu \mathrm{L}$, and the detection was performed with a UV detector set at $214 \mathrm{~nm}$.

Organic acids quantification was achieved by the absorbance recorded in the chromatograms relative to external standards, and the peaks in the chromatograms were integrated using a default baseline construction technique. The detection limit values were calculated as the concentration corresponding to 3 times the standard deviation of the background noise and ranged from 0.2 to $364.0 \mu \mathrm{g} \mathrm{mL}^{-1}$.

HPLC Analysis of Phenolics. An aliquot $(20 \mu \mathrm{L})$ of each extract was analyzed using an analytical HPLC unit (Gilson), with a Spherisorb ODS2 $(25.0 \times 0.46 \mathrm{~cm} ; 5 \mu \mathrm{m}$, particle size $)$ column $(9)$. The solvent system was water-diluted formic acid (19:1) (A) and methanol (B). Elution was performed at a flow rate of $0.9 \mathrm{~mL} \mathrm{~min}^{-1}$, and the gradient was as follows: $5 \% \mathrm{~B}$ at $0 \mathrm{~min}, 15 \% \mathrm{~B}$ at $3 \mathrm{~min}, 25 \% \mathrm{~B}$ at $13 \mathrm{~min}$, $30 \% \mathrm{~B}$ at $25 \mathrm{~min}, 35 \% \mathrm{~B}$ at $35 \mathrm{~min}, 45 \% \mathrm{~B}$ at $39 \mathrm{~min}, 45 \% \mathrm{~B}$ at 42 $\min , 50 \% \mathrm{~B}$ at $44 \mathrm{~min}, 55 \% \mathrm{~B}$ at $47 \mathrm{~min}, 70 \% \mathrm{~B}$ at $50 \mathrm{~min}, 75 \% \mathrm{~B}$ at $56 \mathrm{~min}$, and $80 \% \mathrm{~B}$ at $60 \mathrm{~min}$. Detection was achieved with a Gilson diode array detector. Spectral data from all peaks were accumulated in the range of $200-400 \mathrm{~nm}$, and chromatograms were recorded at 280 $\mathrm{nm}$ for $p$-hydroxybenzoic acid and at $350 \mathrm{~nm}$ for quercetin. The data were processed using a Gilson Unipoint system, and peak purity was checked by the software contrast facilities.

Phenolic compounds were quantified by their absorbances recorded in the chromatograms relative to the corresponding external reference standard. The peaks were integrated using a default baseline construction technique. The detection limit values of $p$-hydroxybenzoic and quercetin were calculated as the concentration corresponding to 3 times the standard deviation of the background noise and corresponded to 3.1 and $4.8 \mu \mathrm{g} \mathrm{mL}^{-1}$, respectively.

DPPH ${ }^{\bullet}$ Scavenging Activity. The antiradical activity of the extracts was determined spectrophotometrically in an ELX808 IU Ultra Microplate Reader (Bio-Tek Instruments, Inc.), by monitoring the disappearance of $\mathrm{DPPH}^{\bullet}$ at $515 \mathrm{~nm}$, according to a described procedure (2). For each mushroom species, the sample with the highest available amount of lyophilized extract was chosen. A dilution series of five different concentrations was prepared in a 96 well plate, and the reaction mixtures in each well consisted of $25 \mu \mathrm{L}$ of aqueous extract and 200 $\mu \mathrm{L}$ of $150 \mathrm{mM} \mathrm{DPPH}$. The reaction was conducted at room temperature during $30 \mathrm{~min}$. Three experiments were performed in triplicate.

\section{RESULTS AND DISCUSSION}

Organic Acids. The HPLC-UV analysis showed that all of the species presented a profile composed of at least five organic acids: oxalic, citric, malic, quinic, and fumaric acids. Several samples also contained aconitic, ketoglutaric, ascorbic, succinic, and shikimic acids (Figure 1; Table 2). Quantification of the identified compounds indicated that malic and quinic acids were the main compounds in all analyzed species $(35-84 \%$ of nonaromatic acids), usually followed by citric acid (9-30\% of nonaromatic acids) (Figure 2).

In all species, ketoglutaric, ascorbic, and shikimic acids were the rarest compounds observed. In addition to these general considerations, it was possible to observe that each species exhibited a distinct organic acids profile (Figure 2; Table 2).

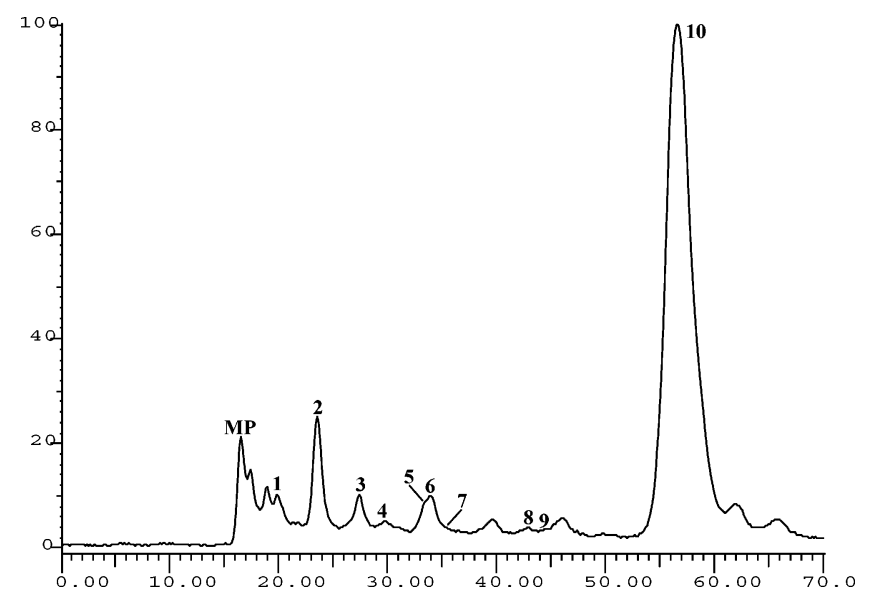

Figure 1. HPLC-UV chromatogram of organic acids in $S$. granulatus (sample 20A). Detection was at $214 \mathrm{~nm}$. Peaks: (MP) mobile phase; (1) oxalic acid; (2) aconitic acid; (3) citric acid; (4) ketoglutaric acid; (5) malic acid; (6) quinic acid; (7) ascorbic acid; (8) succinic acid; (9) shikimic acid; (10) fumaric acid.

In $S$. bellini samples, the pair of malic plus quinic acids is present in highest amounts (42\% of nonaromatic acids), followed by citric acid (20\% of nonaromatic acids). In this species, besides the above-mentioned five common compounds, were also detected succinic and shikimic acids (Figure 2; Table 2). Shikimic acid was the minor compound, representing ca. $0.3 \%$ of identified nonaromatic acids. The total organic acids content of sample 1 was approximately twice that of sample 2, corresponding to ca. 57 and $31 \mathrm{~g} / \mathrm{kg}$, respectively (Table 2). This can be explained by the different weather and soil conditions to which the fields of origin were submitted, but a distinct developmental stage of the fruiting bodies cannot be excluded.

The sum of all quantified acids in $T$. rutilans samples corresponds to ca. $40 \mathrm{~g} / \mathrm{kg}$ (Table 2). This species contains malic and quinic acids as the major compounds (ca. 52\% of nonaromatic acids), followed by citric acid (19\% of nonaromatic compounds) (Figure 2). Aconitic acid appears only in field 2, and shikimic acid was detected only in field 1 . Thus, we could say that $T$. rutilans exhibits a qualitative profile composed by oxalic, citric, malic, quinic, succinic, and fumaric acids (Table 2), but we have not sufficient data to discuss the presence of aconitic and shikimic acids as characteristic of this species. The difference between the samples can be explained by their different fields of origin, as observed above for S. bellini.

The results obtained with $H$. agathosmus allowed us to observe a qualitative profile composed of oxalic, aconitic, citric, ketoglutaric, malic, quinic, succinic, shikimic, and fumaric acids. Quantitatively, the pair malic plus quinic and citric acids were the compounds present in highest amounts, which represents ca. 36 and $30 \%$ of nonaromatic acids, respectively. Shikimic acid was the minor compound, corresponding to ca. $0.2 \%$ of nonaromatic compounds (Figure 2; Table 2). The geographical origin, the orchard provenience, the date of collection, and/or the distinct developmental stage of the fruiting bodies may explain the higher organic acids content of sample 5 relative to that of sample 6 (ca. 84 and $61 \mathrm{~g} / \mathrm{kg}$, respectively) (Table 2).

In $A$. rubescens, it was possible to identify nine compounds: oxalic, aconitic, citric, ketoglutaric, malic, quinic, ascorbic, shikimic, and fumaric acids. Malic and quinic acids were the main compounds, representing ca. $68 \%$ of nonaromatic acids (Figure 2), whereas oxalic acid was detected only in vestigial amounts. This species presented a high total content of organic acids, reaching ca. $91 \mathrm{~g} / \mathrm{kg}$ (Table 2). 
Table 2. Organic Acid Contents of Mushroom Species

\begin{tabular}{|c|c|c|c|c|c|c|c|c|c|c|}
\hline \multirow[b]{2}{*}{ sample } & \multicolumn{10}{|c|}{ organic acida ( $\mathrm{g} / \mathrm{kg}$, dry matter) } \\
\hline & $\begin{array}{c}\text { oxalic } \\
(19.8 \mathrm{~min})^{b}\end{array}$ & $\begin{array}{c}\text { aconitric } \\
(22.7 \mathrm{~min})^{b}\end{array}$ & $\begin{array}{c}\text { citric } \\
(27.4 \mathrm{~min})^{b}\end{array}$ & $\begin{array}{l}\text { ketoglutaric } \\
(29.8 \mathrm{~min})^{b}\end{array}$ & $\begin{array}{c}\text { mailic + quinic } \\
(33.6,34.5 \mathrm{~min})^{b}\end{array}$ & $\begin{array}{c}\text { ascorbic } \\
(35.4 \mathrm{~min})^{b}\end{array}$ & $\begin{array}{c}\text { succinic } \\
(42.6 \mathrm{~min})^{b}\end{array}$ & $\begin{array}{c}\text { shikimic } \\
(43.9 \mathrm{~min})^{b}\end{array}$ & $\begin{array}{c}\text { fumaric } \\
(56.2 \mathrm{~min})^{b}\end{array}$ & total \\
\hline 1 & $3.3(0.03)$ & & $11.2(0.27)$ & & $31.2(1.37)$ & & $5.7(0.30)$ & $0.1(0.00)$ & $5.3(0.07)$ & 56.8 \\
\hline 2 & $1.6(0.11)$ & & $6.2(0.23)$ & & $9.1(0.32)$ & & $6.9(0.37)$ & $0.1(0.01)$ & $7.5(0.11)$ & 31.4 \\
\hline 3 & $2.9(0.05)$ & & $7.8(0.16)$ & & $16.9(0.37)$ & & $8.4(0.45)$ & $0.1(0.01)$ & $3.7(0.03)$ & 39.8 \\
\hline 4 & $0.8(0.00)$ & $2.4(0.30)$ & $6.9(0.28)$ & & $24.1(0.08)$ & & $\mathrm{nq}$ & & $4.9(0.05)$ & 39.1 \\
\hline 5 & $1.6(0.12)$ & $\mathrm{nq}$ & $22.8(2.97)$ & $2.4(0.22)$ & $27.7(0.02)$ & & $8.5(0.45)$ & $0.1(0.01)$ & $21.0(0.67)$ & 84.1 \\
\hline 6 & $2.2(0.18)$ & $1.8(0.00)$ & $20.5(0.06)$ & $2.6(0.00)$ & $23.5(0.48)$ & & $4.4(0.24)$ & $0.1(0.00)$ & $6.2(0.63)$ & 61.3 \\
\hline 7 & $\mathrm{nq}$ & $2.8(0.33)$ & $13.0(0.94)$ & $3.5(0.52)$ & $62.1(0.52)$ & $3.4(0.36)$ & & $0.1(0.01)$ & $6.0(0.02)$ & 90.9 \\
\hline 8 & $0.7(0.01)$ & $\mathrm{nq}$ & $5.8(0.61)$ & & $46.2(4.72)$ & & $\mathrm{nq}$ & & $5.4(0.01)$ & 58.1 \\
\hline 9 & $0.7(0.10)$ & $0.4(0.00)$ & $8.2(0.39)$ & & 71.8 (3.12) & & $0.9(0.17)$ & & $5.3(0.03)$ & 87.3 \\
\hline 10 & $0.5(0.03)$ & $0.1(0.00)$ & $4.3(0.04)$ & & $53.7(0.25)$ & & $2.3(0.10)$ & & $5.6(0.02)$ & 66.5 \\
\hline 11 & $1.4(0.18)$ & $2.3(0.08)$ & $6.2(0.90)$ & & $41.0(0.83)$ & & & & $1.9(0.00)$ & 52.8 \\
\hline 12 & $1.0(0.02)$ & $4.4(0.28)$ & $11.7(1.10)$ & & $38.6(0.76)$ & & & & $1.9(0.00)$ & 57.6 \\
\hline 13 & $2.4(0.00)$ & $2.1(0.06)$ & $7.8(0.07)$ & & $34.1(0.66)$ & & & & $1.7(0.09)$ & 48.1 \\
\hline 14 & $2.6(0.00)$ & $5.2(0.44)$ & $23.7(1.19)$ & & $61.1(0.02)$ & & & & $6.7(0.02)$ & 99.3 \\
\hline 15 & $2.1(0.00)$ & $4.6(0.16)$ & $22.0(0.98)$ & & $57.4(0.60)$ & & & & $7.9(0.00)$ & 94.0 \\
\hline 16 & $\mathrm{nq}$ & & $10.3(5.55)$ & & $45.0(9.17)$ & & $\mathrm{nq}$ & $\mathrm{nq}$ & $12.1(0.44)$ & 67.4 \\
\hline 17 & $2.0(0.00)$ & & $3.8(0.07)$ & & $28.2(0.90)$ & & $2.3(0.53)$ & $\mathrm{nq}$ & $13.8(0.07)$ & 50.1 \\
\hline 18 & $6.9(0.63)$ & & $\mathrm{nq}$ & & $16.6(0.00)$ & & $1.3(0.27)$ & $0.1(0.02)$ & $9.0(0.06)$ & 33.9 \\
\hline 19 & $2.2(0.17)$ & $9.7(0.86)$ & $10.0(3.19)$ & $\mathrm{nq}$ & $19.0(0.44)$ & & $1.4(0.07)$ & & $8.7(0.09)$ & 51.0 \\
\hline $20 \mathrm{~A}$ & $6.2(0.27)$ & $52.7(1.34)$ & $47.9(2.09)$ & $\mathrm{nq}$ & $48.4(7.90)$ & $\mathrm{nq}$ & $1.3(0.00)$ & $\mathrm{nq}$ & $10.4(0.06)$ & 166.9 \\
\hline $20 \mathrm{~B}$ & $2.7(0.46)$ & $38.6(3.11)$ & $25.2(0.97)$ & nq & $35.6(4.15)$ & nq & nq & nq & $18.9(0.06)$ & 121.0 \\
\hline $20 \mathrm{C}$ & $2.8(0.36)$ & $48.7(0.59)$ & $17.5(0.10)$ & $\mathrm{nq}$ & $36.1(0.35)$ & nq & $1.8(0.21)$ & nq & $23.9(0.51)$ & 130.8 \\
\hline 21 & $1.6(0.21)$ & $28.1(0.08)$ & $12.3(0.49)$ & & $29.7(0.11)$ & $\mathrm{nq}$ & $\mathrm{ng}$ & $\mathrm{nq}$ & $24.2(0.95)$ & 95.9 \\
\hline 22 & $0.2(0.03)$ & $3.4(0.03)$ & $1.4(0.11)$ & & $3.6(0.02)$ & $\mathrm{nq}$ & $0.1(0.00)$ & $\mathrm{nq}$ & $1.4(0.01)$ & 10.1 \\
\hline 23 & $1.6(0.20)$ & $36.1(2.51)$ & $15.8(5.22)$ & & $22.7(0.05)$ & $\mathrm{nq}$ & nq & $\mathrm{nq}$ & $11.9(0.05)$ & 88.1 \\
\hline $24 \mathrm{~A}$ & $5.7(0.00)$ & $10.4(0.42)$ & $14.4(0.94)$ & $\mathrm{nq}$ & $42.6(0.65)$ & $\mathrm{nq}$ & $\mathrm{nq}$ & $\mathrm{nq}$ & $10.1(0.19)$ & 83.2 \\
\hline $24 \mathrm{~B}$ & $3.3(0.09)$ & $18.2(3.26)$ & $17.2(0.51)$ & $\mathrm{nq}$ & $66.8(3.79)$ & $\mathrm{nq}$ & $2.2(0.06)$ & $0.3(0.03)$ & $20.7(0.66)$ & 128.7 \\
\hline $24 \mathrm{C}$ & $2.2(0.08)$ & $12.3(1.56)$ & $8.8(0.43)$ & $\mathrm{nq}$ & $31.7(0.20)$ & $\mathrm{nq}$ & nq & $\mathrm{nq}$ & $20.6(0.00)$ & 75.6 \\
\hline 25 & $0.3(0.02)$ & $1.5(0.06)$ & $1.7(0.27)$ & & $5.0(0.26)$ & & $0.2(0.03)$ & & $1.7(0.16)$ & 10.4 \\
\hline 26 & $2.9(0.03)$ & $26.5(2.38)$ & $30.0(0.46)$ & $\mathrm{nq}$ & $20.2(0.11)$ & $\mathrm{nq}$ & $2.2(0.30)$ & $0.1(0.01)$ & $10.4(0.22)$ & 92.3 \\
\hline 27 & $2.6(0.02)$ & $29.4(1.16)$ & $27.5(4.35)$ & $\mathrm{nq}$ & $29.1(0.72)$ & $\mathrm{nq}$ & $2.2(0.58)$ & $0.3(0.01)$ & $17.1(0.26)$ & 108.2 \\
\hline 28 & $2.0(0.00)$ & $12.0(0.08)$ & $13.2(0.00)$ & $\mathrm{nq}$ & $21.6(2.54)$ & $\mathrm{nq}$ & $1.8(0.82)$ & $\mathrm{nq}$ & $28.2(0.00)$ & 78.8 \\
\hline
\end{tabular}

\footnotetext{
${ }^{a}$ Results are expressed as mean (standard deviation) of three determinations. nq, not quantified. ${ }^{b}$ Retention time.
}

If we compare the three samples, collected in three different fields, of $R$. cyanoxantha species, it is clear that there is a perfectly defined organic acids profile, composed by oxalic, aconitic, citric, malic, quinic, succinic, and fumaric acids (Table 2). This species contains the pair malic plus quinic acids as the major compounds, corresponding to ca. $81 \%$ of total acids and aconitic as the minor one, representing ca. $0.2 \%$ of organic acids (Figure 2). Nevertheless, the total of organic acids ranged from ca. 58 to $87 \mathrm{~g} / \mathrm{kg}$, which can be related with the field of origin and/or with the distinct developmental stage of the fruiting bodies.

B. edulis presents a qualitative profile composed by oxalic, aconitic, citric, malic, quinic, and fumaric acids (Figure 2). The sum of all quantified acids in B. edulis samples ranged from ca. 48 to $58 \mathrm{~g} / \mathrm{kg}$ (Table 2), containing the pair malic plus quinic acid in major amounts (ca. $71 \%$ of nonaromatic acids), and oxalic acid as the minor compound, representing $3 \%$ of organic acids (Figure 2).

When the results obtained in this study for $B$. edulis are compared with those from a previous work (8), the absence of succinic and ketoglutaric acids can be observed, whereas aconitic acid is now described for the first time. The differences found in the organic acids profile can be explained by the distinct field of origin and/or year of collection.

With respect to $T$. equestre, the results showed a qualitative profile identical to that of B. edulis (Figure 2). The sum of all quantified acids ranged from ca. 94 to $99 \mathrm{~g} / \mathrm{kg}$ (Table 2), in which malic and quinic acids, corresponding to ca. $61 \%$ of nonaromatic compounds, followed by citric acid, representing ca. $24 \%$ of organic acids, were the compounds in highest amounts. Oxalic acid was found in the smallest amounts (ca. $2 \%$ of nonaromatic acids) (Figure 2 ).

S. luteus samples exhibited six organic acids, namely, oxalic, citric, malic, quinic, succinic, and fumaric acids, with malic plus quinic acids as the major compounds (Figure 2). However, samples from Vinhais (samples 16-18), additionally presented shikimic acid, whereas that from Bragança (sample 19) also exhibited aconitic and ketoglutaric acids. Therefore, the differences found between the two geographical origins (Vinhais and Bragança) indicate that this factor may interfere with the organic acids composition of this species. Despite this, the total organic acids content of the $S$. luteus sample from Bragança (ca. 51 $\mathrm{g} / \mathrm{kg}$ ) is within the range registered for the samples collected in Vinhais (ca. 34-67 g/kg) (Table 2). The variation in Vinhais samples may be attributed to the fields of origin and/or the distinct developmental stage of the fruiting bodies.

If we compare $S$. granulatus samples from diverse geographical origins (Table 2), we can see that this species follows a qualitative profile composed of oxalic, aconitic, citric, ketoglutaric, malic, quinic, ascorbic, succinic, shikimic, and fumaric acids, with the exceptions of the samples from Macedo de Cavaleiros (samples 21-23), in which ketoglutaric acid does not appear, and that from Vila Flor (sample 25), which does not present ketoglutaric, ascorbic, and shikimic acids. For $S$. granulatus samples from Vinhais and Vila Flor (samples 24A, 24B, 24C, and 25), the pair malic plus quinic acids presented the highest amounts, corresponding to ca. $48 \%$ of nonaromatic acids, whereas for those from Carrazeda de Ansiães (samples 20A, 20B, and 20C) and Macedo de Cavaleiros (samples 2123), aconitic acid was revealed to be the major compound, 
S. bellini

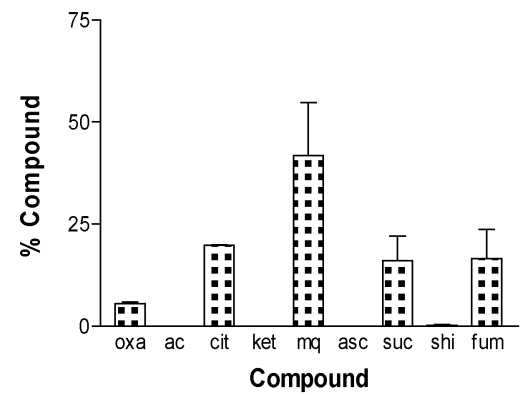

A. rubescens

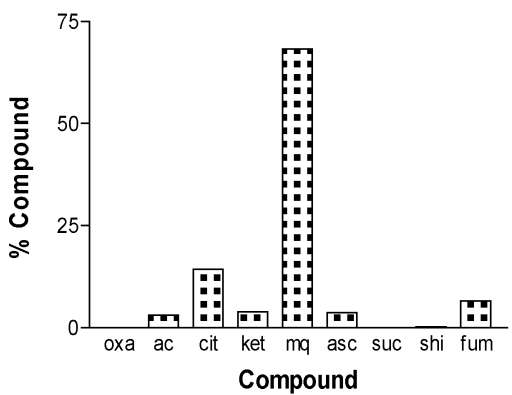

$T$. equestre

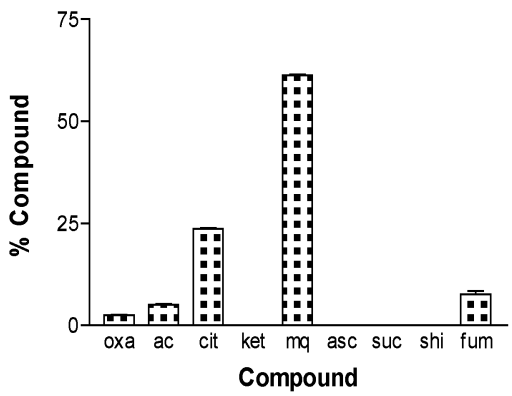

T. rutilans

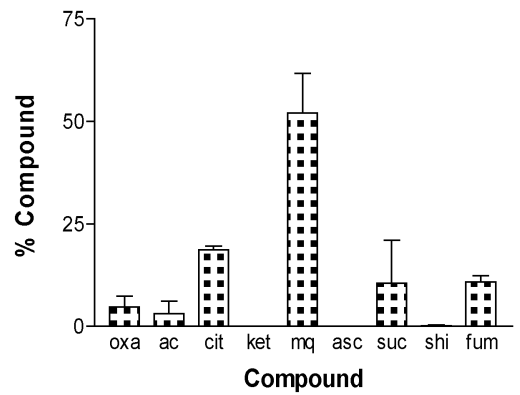

R. cyanoxantha

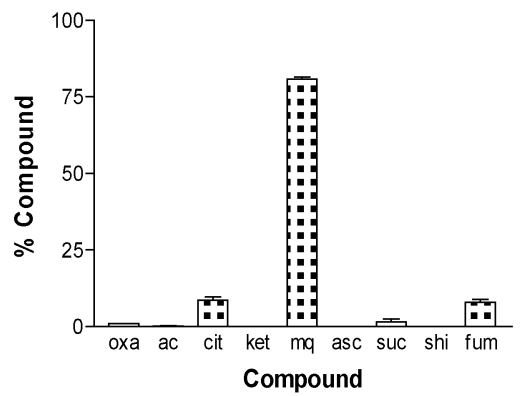

S. Iuteus

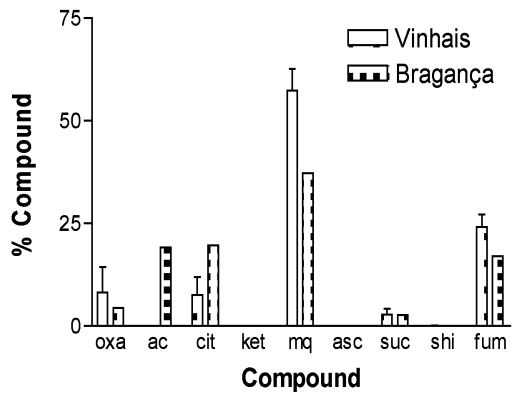

H. agathosmus

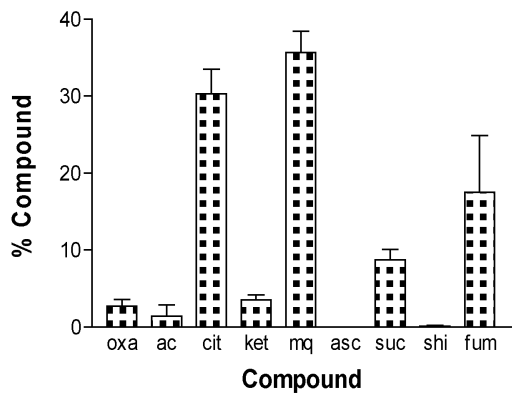

B. edulis

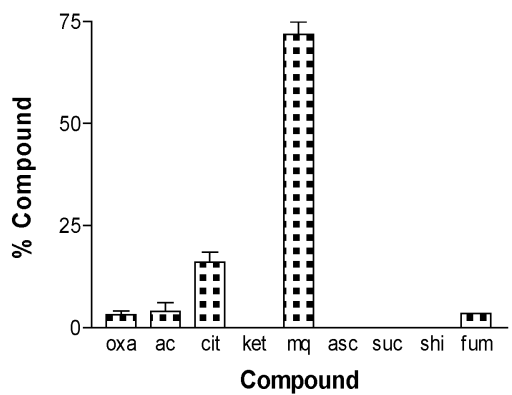

S. granulatus

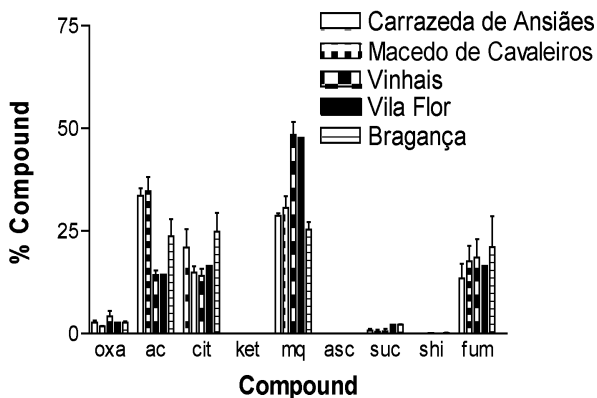

Figure 2. Organic acids profile of edible mushrooms species. Values represent mean, and standard error bars are on the top of each column. Abbreviations: (oxa) oxalic acid; (ac) aconitic acid; (cit) citric acid; (ket) ketoglutaric acid; (mq) malic plus quinic acids; (asc) ascorbic acid; (suc) succinic acid; (shi) shikimic acid; (fum) fumaric acid.

representing ca. 34 and $35 \%$ of organic acids, respectively (Figure 2). Samples from Bragança (samples 26-28) presented some quantitative variability between them. Besides this, we can see that aconitic, citric, the pair malic plus quinic, and fumaric acids are the major compounds, each ranging from ca. 21 to $25 \%$ of nonaromatic acids. The compound presented in smallest amounts in Carrazeda de Ansiães, Macedo de Cavaleiros, and Vila Flor samples was succinic acid, corresponding to $0.7,0.5$, and $2 \%$ of organic acids, respectively. In those from Vinhais and Bragança the minor compound was shikimic acid, representing 0.07 and $0.1 \%$ of the total identified compounds (Figure 2). Thus, according to these results, the geographical origin of the samples seems to influence the organic acids composition of this species. In addition to the environmental factors, also the developmental stage of the fruiting bodies may be responsible for the wide range of nonaromatic acid contents registered in $S$. granulatus samples.

The sum of the identified acids in all $S$. granulatus samples ranged from ca. 10 to $167 \mathrm{~g} / \mathrm{kg}$ (Table 2). Except for samples 22 and 25, S. granulatus is, in general, the species with highest amounts of organic acids, whereas $T$. rutilans presented the lowest ones.

Phenolic Compounds. After the screening tests with $\mathrm{NaOH}$ $20 \%$ and $\mathrm{FeCl}_{3} 4.5 \%$ to find which species contained phenolic compounds, only $S$. bellini, A. rubescens, $R$. cyanoxantha, $B$. edulis, T. equestre, S. luteus, and S. granulatus revealed the presence of these secondary metabolites in the methanolic extracts.

Then, the HPLC-DAD analysis allowed the identification of $p$-hydroxybenzoic acid in $A$. rubescens, $R$. cyanoxantha, and $T$. equestre species and quercetin in $S$. luteus and $S$. granulatus. Other extraction solvents were used, namely, hydromethanol and water, presenting for all of the extracts the same qualitative compositions and similarities in the quantitative analysis. Both compounds were present in very small amounts (Table 3). In the other species for which positive results were obtained in the screening tests ( $S$. bellini and B. edulis) it was not possible to identify any phenolic compound.

The existence of $p$-hydroxybenzoic acid could be useful to the quality control of $R$. cyanoxantha and $T$. equestre species because it was detected in all of the samples of each species (Table 3). Relative to A. rubescens, we studied only one sample; thus, more samples should be studied to determine if the presence of $p$-hydroxybenzoic acid is characteristic of this species. Concerning the presence of quercetin, it can be observed that the sample of S. luteus from Bragança (sample 19) and those of $S$. granulatus from Vinhais (samples 24A, 24B, and $24 \mathrm{C}$ ) and Vila Flor (sample 25) do not exhibit this compound 
Table 3. Phenolics Contents of Mushroom Species

\begin{tabular}{|c|c|c|}
\hline \multirow[b]{2}{*}{ sample } & \multicolumn{2}{|c|}{ compounda (mg/kg, dry matter) } \\
\hline & $\begin{array}{l}\text { p-hydroxybenzoic } \\
\text { acid }(13.8 \mathrm{~min})^{b}\end{array}$ & $\begin{array}{l}\text { quercetin } \\
(51.3 \mathrm{~min})^{b}\end{array}$ \\
\hline \multicolumn{3}{|l|}{1} \\
\hline \multicolumn{3}{|l|}{2} \\
\hline \multicolumn{3}{|l|}{3} \\
\hline \multicolumn{3}{|l|}{4} \\
\hline \multicolumn{3}{|l|}{5} \\
\hline \multicolumn{3}{|l|}{6} \\
\hline 7 & $490.9(0.0)$ & \\
\hline 8 & $\mathrm{nq}$ & \\
\hline 9 & $\mathrm{nq}$ & \\
\hline 10 & $\mathrm{nq}$ & \\
\hline \multicolumn{3}{|l|}{11} \\
\hline \multicolumn{3}{|l|}{12} \\
\hline \multicolumn{3}{|l|}{13} \\
\hline 14 & 116.3 (23.4) & \\
\hline 15 & $35.5(0.0)$ & \\
\hline 16 & & \\
\hline 17 & & $4.6(0.0)$ \\
\hline 18 & & $\mathrm{nq}$ \\
\hline \multicolumn{3}{|l|}{19} \\
\hline $20 \mathrm{~A}$ & & $15.9(0.0)$ \\
\hline $20 \mathrm{~B}$ & & $\mathrm{nq}$ \\
\hline $20 \mathrm{C}$ & & $2.0(0.0)$ \\
\hline 21 & & $12.1(0.0)$ \\
\hline 22 & & $\mathrm{nq}$ \\
\hline 23 & & $\mathrm{nq}$ \\
\hline \multicolumn{3}{|l|}{$24 \mathrm{~A}$} \\
\hline \multicolumn{3}{|l|}{$24 B$} \\
\hline \multicolumn{3}{|l|}{$24 \mathrm{C}$} \\
\hline \multicolumn{3}{|l|}{25} \\
\hline 26 & & $\mathrm{nq}$ \\
\hline 27 & & $5.9(0.0)$ \\
\hline 28 & & $\mathrm{nq}$ \\
\hline
\end{tabular}

\footnotetext{
${ }^{a}$ Results are expressed as mean (standard deviation) of three determinations. nq, not quantified. ${ }^{b}$ Retention time.
}

(Table 3). These findings clearly suggest an influence of the geographical origin in the phenolic composition of these two species.

The results obtained show that the nine studied mushroom species contain very small amounts of phenolics (Table 3), which is in accordance with previous works that refer to the occurrence of low contents of these compounds in mushrooms (9). When compared with organic acids, phenolics are present in notably lower contents. In addition, among samples of the same species and with the same origin (samples 14 and 15, samples 16-18, samples 21-23, and samples 26-28), the amounts of the identified phenolic compounds are clearly different, indicating a possible interference of the collection field. On the other hand, the influence of the development stage of the analyzed individuals cannot be excluded, as observed with different quercetin contents obtained with samples 20A, 20B, and 20C (Table 3).

In addition, from a botanical point of view, the chemical composition of $S$. bellini may be useful in its distinction from the other two analyzed Suillus species ( $S$. granulatus and $S$. luteus): it presents a clearly distinct organic acids profile, exhibiting no aconitic acid and a higher succinic acid relative amount (Figure 2), and does not present quercetin (Table 3).

Antioxidant Activity. The $\mathrm{DPPH}^{\bullet}$ test is a commonly employed assay in antioxidant studies of specific compounds or extracts across a short time scale. Unlike laboratory-generated free radicals, the $\mathrm{DPPH}^{\bullet}$ assay has the advantage of being unaffected by certain side reactions, such as metal ion chelation and enzyme inhibition $(11,50)$. A freshly prepared $\mathrm{DPPH}^{\circ}$
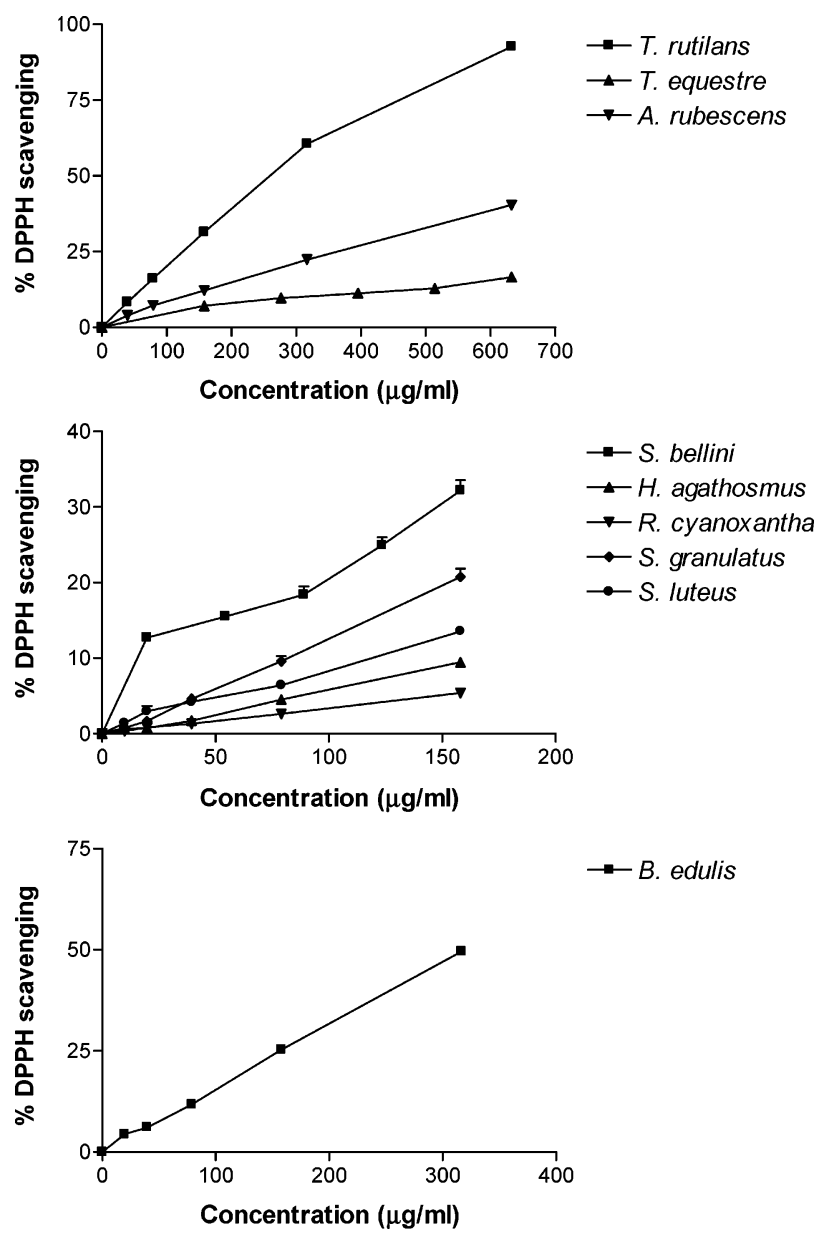

Figure 3. Effect of the studied mushroom species on DPPH • reduction. Values show mean \pm SE from three experiments performed in triplicate.

solution exhibits a purple color with absorption maximum at $515 \mathrm{~nm}$. This purple color generally disappears when antioxidants are present in the medium. Thus, antioxidant molecules can quench $\mathrm{DPPH}^{\bullet}$ free radicals (i.e., by providing hydrogen atoms or by electron donation, conceivably via a free radical attack on the $\mathrm{DPPH}^{\bullet}$ molecule), and convert them into a colorless/bleached product, resulting in a decrease in absorbance at $515 \mathrm{~nm}$. Hence, the more rapidly the absorbance decreases, the more potent the antioxidant activity of the extract.

From the analysis of Figure 3, we can conclude that the scavenging effects of all of the studied mushroom species were concentration-dependent. At $150 \mu \mathrm{g} \mathrm{mL}^{-1}$, the reducing power was $>5 \%$ and followed the order T. rutilans $>$ S. bellini $>B$. edulis $>S$. granulatus $>S$. luteus $\approx A$. rubescens $>H$. agathosmus $>T$. equestre $\approx R$. cyanoxantha. $T$. rutilans and $S$. bellini revealed moderate antioxidant properties, but, in general, the analyzed mushroom species displayed very low antioxidant potential (Figure 3). Nevertheless, when the antioxidant activities of $T$. rutilans and $S$. bellini are compared with those of other edible mushrooms species, it could be noted that, with regard to the DPPH assay, these species present a better result $(11-14)$.

No correlation was found between organic acids total amount and antioxidant potential in the studied extracts. The total amount of organic acids in the studied samples follows the order $S$. granulatus $>T$. equestre $\approx A$. rubescens $>R$. cyanoxantha $>$ S.luteus $\approx B$. edulis $>$ S. bellini $\approx T$. rutilans. The species containing the highest organic acid contents ( $S$. granulatus, $T$. equestre, and $A$. rubescens) present low $\mathrm{DPPH}^{\bullet}$ scavenging abilities. In contrast, the species that contain minor amounts of 
organic acids (B. edulis, S. bellini, and T. rutilans) are those presenting the highest scavenging activity.

Concerning phenolic compounds, despite their antioxidant properties, especially when they contain hydroxyl groups, as reported in previous works for $p$-hydroxybenzoic acid (51) and quercetin (52), there was not also found a positive correlation between the scavenging ability and the phenolic content of the extracts. The species with the highest phenolic amount was $A$. rubescens (sample 7), for which the scavenging capacity reached only $12 \%$ at the tested concentrations. In fact, $T$. rutilans, $B$. edulis, and S. bellini, which showed the highest antioxidant potential, are those species in which $p$-hydroxybenzoic acid and quercetin were not present, indicating that these compounds, in such very small amounts, do not contribute to the antioxidant activity of the mushroom extracts.

In conclusion, the results obtained in this work indicate that the analyzed mushroom species constitute a rich dietary source of organic acids. Each species presented a distinct profile, suggesting that these metabolites may be used for their quality control. Further studies with samples from other origins should be performed to check the influence of the geographical origin in the organic acids profile. With regard to the antioxidant activity, these species can hardly provide an effective protection. This study gives a considerable contribution to the knowledge of several mushroom species extensively used for human consumption.

\section{LITERATURE CITED}

(1) Halliwell, B. Reactive oxygen species in living systems: source, biochemistry and role in human disease. Am. J. Med. 1991, 91, S14-S22.

(2) Silva, B. M.; Andrade, P. B.; Valentão, P.; Ferreres, F.; Seabra, R. M.; Ferreira, M. A. Quince (Cydonia oblonga Miller) fruit (pulp, peel and seed) and jam: antioxidant activity. J. Agric. Food Chem. 2004, 52, 4705-4712.

(3) Vaughan, J. G.; Geissler, C. A. The New Oxford Book of Good Plants; Oxford University Press: New York, 1997; p 196.

(4) Vrchovská, V.; Sousa, C.; Valentão, P.; Ferreres, F.; Pereira, J. A.; Seabra, R. M.; Andrade, P. B. Antioxidative properties of tronchuda cabbage (Brassica oleracea L. var. costata DC) external leaves against DPPH, superoxide radical, hydroxyl radical and hypochlorous acid. Food Chem. 2006, 98, 416-425.

(5) Valentão, P.; Andrade, P. B.; Areias, F.; Ferreres, F.; Seabra, R. M. Analysis of vervain flavonoids by HPLC/diode-array detector. Its application to quality control. J. Agric. Food Chem. 1999, 47, 4579-4582.

(6) Guthrie, N.; Kurowska, E. M. N. Anticancer and cholesterollowering activities of citrus flavonoids. In Handbook of Nutraceuticals and Functional Foods; Wildman, R. E. C., Ed.; CRC: Boca Raton, FL, 2001; pp 113-126.

(7) Manzi, P.; Aguzzi, A.; Pizzoferrato, L. Nutritional value of mushrooms widely consumed in Italy. Food Chem. 2001, 73, 321-325.

(8) Valentão, P.; Lopes, G.; Valente, M.; Barbosa, P.; Andrade, P. B.; Silva, B. M.; Baptista, P.; Seabra, R. M. Quantification of nine organic acids in wild edible mushrooms. J. Agric. Food Chem. 2005, 53, 3626-3630.

(9) Valentão, P.; Andrade, P. B.; Rangel, J.; Ribeiro, B.; Silva, B. M.; Baptista, P.; Seabra, R. M. Effect of the conservation procedure on the contents of phenolic compounds and organic acids in chanterelle (Cantharellus cibarius) mushroom. J. Agric. Food Chem. 2005, 53, 4925-4931.

(10) Mattilla, P.; Könkö, K.; Eurola, M.; Pihlava, J.-M.; Astola, J.; Vahteristo, L.; Hietaniemi, V.; Kumpulainen, J.; Valtonen, M.; Piironen, V. Contents of vitamins, mineral elements and some phenolic compounds in cultivated mushrooms. J. Agric. Food Chem. 2001, 49, 2343-2348.
(11) Ferreira, C. F. R.; Baptista, P.; Vilas-Boas, M.; Barros, L. Freeradical scavenging capacity and reducing power of wild edible mushrooms from northeast Portugal: individual cap and stipe activity. Food Chem. 2006, in press.

(12) Cheung, L. M.; Cheung, P. C. K.; Ooi, V. E. C. Antioxidant activity and total phenolics of edible mushroom extracts. Food Chem. 2003, 81, 249-255.

(13) Lo, K. M.; Cheung, P. C. K. Antioxidant activity of extracts from the fruiting bodies of Agrocybe aegerita var. alba. Food Chem. 2005, 89, 533-539.

(14) Yang, J.-H.; Lin, H.-C.; Mau, J.-L. Antioxidant properties of several commercial mushrooms. Food Chem. 2002, 77, 229235.

(15) Murcia, M. A.; Martínez-Tomé, M.; Jiménez, A. M.; Vera, A. M.; Honrubia, M.; Parras, P. Antioxidant activity of edible fungi (truffles and mushrooms): losses during industrial processing. J. Food Prot. 2002, 10, 1614-1622.

(16) Koch, J.; Witt, S.; Liberra, K.; Lindequist, U. The influence of extracts of Tricholomopsis rutilans (schff.ex fr.) sing. on the binding of LPS to CD14+- cells and on the release of inflammatory mediators. Phytother. Res. 1998, 12, 27-29.

(17) Wang, F.; Liu, J. K. Two new steryl esters from the basidiomycete Tricholomopsis rutilans. Steroids 2005, 70, 127-130.

(18) Wells, J. M.; Boddy, L. Translocation of soil-derived phosphorus in mycelial cord systems in relation to inoculum resource size. FEMS Microbiol. Ecol. 1995, 17, 67-75.

(19) Mullersman, J. E.; Preston, J. F. A microassay for phallotoxins: quantification of phallotoxins in Amanita species. Anal. Biochem. 1982, 119, 266-273.

(20) Aruguete, D. M.; Aldstadt, J. H., III; Mueller, G. M. Accumulation of several heavy metals and lanthanides in mushrooms (Agaricales) from the Chicago region. Sci. Total Environ. 1998, 224, 43-56.

(21) White, R. L.; Wentzell, P. D.; Grund, M. A. B. D. S. C. W. Taxonomy of Amanita mushrooms by pattern recognition of amino acid chromatographic data. Anal. Chim. Acta 1993, 277, $333-346$.

(22) Seeger, R.; Odenthal, K. P.; Mengs, U. Toxic effects in mouse and rat of rubescenslysin from Amanita rubescens. Toxicon 1981, 19, 409-417.

(23) Demirbas, A. Heavy metal bioaccumulation by mushrooms from artificially fortified soils. Food Chem. 2001, 74, 293-301.

(24) Demirbas, A. Concentrations of 21 metals in 18 species of mushrooms growing in the East Black Sea region. Food Chem. 2001, 75, 453-457.

(25) Agerer, R. Impacts of artificial rain and liming on fruitbody production of ectomycorrhizal fungi. Agr. Ecosyst. Environ. 1990, 28, 3-8.

(26) Nikkarinen, M.; Mertanen, E. Impact of geological origin on trace element composition of edible mushrooms. J. Food Compos. Anal. 2004, 17, 301-310.

(27) Kalad, P.; Burda, J.; Stašková, I. Concentrations of lead, cadmium, mercury and cooper in mushrooms in the vicinity of a lead smelter. Sci. Total Environ. 1991, 105, 109-119.

(28) Manzi, P.; Marconi, S.; Aguzzi, A.; Pizoferrato, L. Commercial mushrooms: nutritional quality and effect of cooking. Food Chem. 2004, 84, 201-206.

(29) Thomas, A. F. An analysis of the flavour of the dried mushroom, Boletus edulis. J. Agric. Food Chem. 1973, 21, 955-958.

(30) Salerni, E.; Perini, C. Experimental study for increasing productivity of Boletus edulis s.l. in Italy. Forest Ecol. Manag. 2004, 201, 161-170.

(31) Bruhn, J. N.; Soderberg, M. D. Allergic contact dermatitis caused by mushrooms. A case report and literature review. Mycopathologia 1991, 115, 191-195.

(32) Rozycki, H.; Strzelezyk, E. Free amino acid production by ectomycorrhizal fungi of pine (Pinus sylvestris L.). Acta Microbiol. Pol. 1985, 34, 59-66.

(33) Stijve, T. Selenium content of mushrooms. Z. Lebensm. Unters. Forsch. 1997, 164, 201-203. 
(34) Dvořák, P.; Kunová, V.; Beňová, K. Exponential drop of radiocesium activity in mushrooms due to the effect of acetic acid. Eur. Food Res. Technol. 2006, 222, 139-143.

(35) Moor, D.; Brodmann, P.; Nicholas, G.; Eugster, A. Polymerase chain reaction (PCR) for the detection of king bolete (Boletus edulis) and slippery jack (Suillus luteus) in food samples. Eur. Food Res. Technol. 2002, 214, 340-345.

(36) Cullings, K. W.; New, M. H.; Makhija, S.; Parker, V. T. Effects of litter addition on ectomycorrhizal associates of a Lodgepole Pine (Pinus contorta) stand in Yellowstone National Park. Appl. Environ. Microbiol. 2003, 69, 3772-3776.

(37) Falandysz, J.; Marcinowicz, A.; Chwir, A. Mercury in edible mushrooms from the area of Kosciersk forests and from the Vistula península. Rocz. Panstw. Zakl. Hig. 1996, 47, 205-210.

(38) Muramatsu, Y.; Yoshida, S.; Sumiya, M. Concentrations of radiocesium and potassium in basidiomycetes collected in Japan. Sci. Total Environ. 1991, 105, 29-39.

(39) Mdachi, S. J. M.; Nkunya, M. H. H.; Nyigo, V. A.; Urasa, I. T. Amino acid composition of some Tanzanian wild mushrooms. Food Chem. 2004, 86, 179-182.

(40) Manian, S.; Sreenvisaprasad, S.; Bending, G. D.; Mills, P. R. Genetic diversity and interrelationships among common European Suillus species based on ribosomal DNA sequences. FEMS Microbiol. Lett. 2001, 204, 117-121.

(41) Chodorowski, Z.; Anand, J. S.; Grass, M. Acute poisoning with Tricholoma equestre of five-year old child. Przegl Lek. 2003, 60, 309-10.

(42) Bedry, R.; Baudrimont, I.; Deffieux, G.; Creppy, E. E.; Pomies, J. P.; Dupon, M.; Gabinski, C.; Chapalain, J. C. Wild-mushroom intoxication as a cause of rhabdomyolysis. N. Engl. J. Med. 2001 $345,798-802$.

(43) Bas, C.; Kuyper, T. H. W.; Noordeloos, M. E., Vellinga, E. C. In Flora Agaricina Neerlandica; critical monographs on families of agarics and boleti occuring in The Netherlands; Balkema: Rotterdam, The Netherlands, 1990-2001; Vol. 1-5.
(44) Bon, M. In Guia de Campo de los Hongos de Europa; Ediciones Omega: Barcelona, Spain, 1988.

(45) Courtecuisse, R.; Duhem, B. In Mushrooms and Toadstools of Britain and Europe; HarperCollins Publishers: London, U.K., 1995.

(46) Courtecuisse, R. In Mushrooms of Britain and Europe; HarperCollins Publishers: London, U.K., 1999.

(47) Marchand, A. In Champignons du Nord et du Midi; Soc. Mycol. Pyrénées Mediterranéenes: Perpignan, France, 1971-1986; Vol. $1-9$.

(48) Moser, M. In Keys to Agarics and Boleti (Poliporales, Boletales, Agaricales, Russulales); Roger Phillips: London, U.K., 1983.

(49) Ferreres, F.; Sousa, C.; Vrchovská, V.; Valentão, P.; Pereira, J. A.; Seabra, R. M.; Andrade, P. B. Chemical composition and antioxidant activity of tronchuda cabbage internal leaves. Eur. Food Res. Technol. 2005, 222, 88-98.

(50) Amarowicz, R.; Pegg, R. B.; Rahimi-Moghaddam, P.; Barl, B.; Weil, J. A. Free-radical scavenging capacity and antioxidant activity of selected plant species from the Canadian prairies. Food Chem. 2004, 84, 551-562.

(51) Natella, F.; Nardini, M.; Di Felice, M.; Scaccini, C. Benzoic and cinnamic acid derivatives as antioxidants: structure-activity relation. J. Agric. Food Chem. 1999, 47, 1453-1459.

(52) Meyer, A. S.; Heinonen, M.; Frankel, E. N. Antioxidant interactions of catechin, cyanidin, caffeic acid, quercetin and ellagic acid on human LDL oxidation. Food Chem. 1998, 61, $71-75$.

Received for review July 6, 2006. Revised manuscript received September 5, 2006. Accepted September 7, 2006. B.R. is indebted to Fundação para a Ciência e a Tecnologia for a grant (SFRH/BD/ 22108/2005).

JF061890Q 